\title{
BMJ Global Health Global health beyond geographical boundaries: reflections from global health education
}

\author{
Sibylle Herzig van Wees (D) , ${ }^{1}$ Hampus Holmer ${ }^{2,3}$
}

To cite: Herzig van Wees S, Holmer H. Global health beyond geographical boundaries: reflections from global health education. BMJ Global Health 2020;5:e002583. doi:10.1136/ bmjgh-2020-002583

SHvW and $\mathrm{HH}$ contributed equally.

Received 3 April 2020 Accepted 6 April 2020

\section{Check for updates}

\section{(C) Author(s) (or their} employer(s)) 2020. Re-use permitted under CC BY-NC. No commercial re-use. See rights and permissions. Published by BMJ.

${ }^{1}$ UGHRIS - Uppsala Global Health Research on Implementation and Sustainability, Department of Women's and Children's Health, Uppsala Universitet, Uppsala, Sweden

${ }^{2}$ Department of Global Public Health, Karolinska Institute, Stockholm, Sweden ${ }^{3}$ Center for Policy Impact in Global Health, Duke Global Health Institute, Duke University, Durham, North Carolina, USA

\section{Correspondence to} Dr Sibylle Herzig van Wees; sibylle.herzigvanwees@kbh. uu.se

\section{INTRODUCTION}

As global health educators and researchers from Sweden, we read King and Koski's ${ }^{1}$ argument that global health should be defined as 'public health somewhere else' with interest and recognition. Often, global health has been and still is being taught and practised precisely in this way, too often without critical reflection about expertise, accountability and inefficiency, as pointed out by the authors. From our experience of teaching global health, two themes both confirm and challenge the notion of global health as public health somewhere else: the experience and demands of global health students, and the existence of global health problems in our local setting. In this commentary, drawing on examples from global health education, we call for an urgent revision of current teaching practices. In order to do so, we propose a reframing of the global health definition with a move away from a focus on geographical boundaries and instead focus on the global scope of the discipline.

\section{EXPERIENCES FROM GLOBAL HEALTH EDUCATION}

Global health curricula often focus on health issues not only 'somewhere else', but specifically in low-income countries. In our global health teaching, we often encounter students from low-income countries who are disappointed to learn about their countries of origin-of which they may be the true experts. While originating from somewhere does not automatically make you an expert, there are examples where students have even been offended because of the simplistic way in which their countries have been described by lecturers. Moreover, students who want to do a global health master thesis on a health issue in Sweden have been discouraged to do so and are instead asked to focus on a lowincome country. We feel that it is paramount

\section{Summary box}

Our experience suggests that global health is often taught as 'public health somewhere else'.

- However, the experience and demands of global health students and pressing global health issues in all settings require a different approach.

- We, therefore, suggest that a more useful definition of global health is to move beyond the notion of geographical boundaries, with 'global' instead referring to a holistic, multidisciplinary perspective of health.

- We suggest that current global health educational practices include a broader disciplinary scope and focus on educational examples from throughout the world, including one's own local context.

that global health education is relevant to all students, not only those from high-income countries. In particular, we applaud the student-led 'Decolonize Global Health' movement, which is challenging not only such simplistic notions of global health, but also the 'depoliticized and ahistorical' manner in which global health is taught. ${ }^{2}$

Pressing health issues exist in all countries, and in the best of worlds, global health education can provide both tools and curiosity to explore these issues in any setting, including high-income settings. Meanwhile, global health courses particularly in undergraduate medical education including medical schools frequently include field visits to lowincome countries. These courses are very popular, but not entirely unproblematic. On the one hand, experiencing a context different from one's own can be a transformative experience, hard to come by without travelling, but on the other hand they may reinforce the idea that global health is about health somewhere else, decreasing interest in health issues at home while carrying a huge carbon footprint and perpetuating colonial or neocolonial practices. The latter is particularly true when such experiential learning is 
not sufficiently narrated by teachers. ${ }^{34}$ In a similar vein, we have observed that medical students often appear to lack interest in traditional public health and social medicine courses within the medical curriculum, but 'global health', which covers much the same subjects, is seen as interesting, perhaps due to the perception that it is somehow exotic and involves international travel.

There are several reasons that can explain why we teach global health as public health somewhere else. Global health emerged from tropical medicine and international health, ${ }^{5}$ and there are remnants of that in many departments, reflected in a lingering resistance to changing the name of departments, curricula or teaching practices. Moreover, because global health has its history in tropical medicine, many global health teaching programmes are located in schools or faculties of medicine, rendering it challenging to shift towards a curriculum highlighting the social sciences.

\section{BEYOND GEOGRAPHICAL BOUNDARIES: TOWARDS A NEW DEFINITION}

If global health is not about health somewhere else, what does it constitute? We suggest that teaching global health should prioritise the development skills and perspectives necessary to understand health and how it can be improved, which can be applied to any setting or context, and less about learning about health issues in low-income countries. Topics such as health equity, health systems and global health politics invariably generate discussion about students' local context and experiences, wherever they may be. We believe that separating such discussions between a local and a global context-particularly when it involves the common phrase in definitions of global health: 'those health issues that transcend national boundaries'-is counterproductive. It is not clear when a health issue transcends a national boundary, and frequently, understanding health issues in their national, subnational, historical, political, cultural and economic context is far more helpful, even if it is not 'somewhere else'. Therefore, we believe that it is crucial that the definition of global health moves beyond geographical boundaries. We interpret the word 'global' in its abstract sense-'of, relating to, or applying to a whole'. ${ }^{6}$ Thus global health is about taking a holistic perspective of 'health', or about the disciplinary scope rather than its geographical reach.

There are some encouraging examples suggesting a move away from global health as public health somewhere else. For example, the recent renaming of the Karolinska Institute Department of Global Public Health suggests that the separation between those working in global health and those working in local health is reducing. The elective Global Medicine course for medical students at Uppsala University offers students to remain in Sweden as opposed to going abroad to gain practical experience in global health. The COVID-19 pandemic has accelerated the development of local and online global health learning activities replacing international travel. While such examples are promising, we propose further efforts to emphasise the global scope of health as opposed to the geographical reach. This includes getting students in our global health courses to reflect on health inequalities in their own society. We believe that the notion that global health is something that occurs abroad contributes to a demand for short international electives-usually presented without mention of ethical issues and their carbon footprint-while at the same time undercutting efforts to address health issues at home. Indeed, while there is great enthusiasm for 'doing global health' by travelling abroad to practise as a nurse or doctor, exceedingly few are interested in contributing to health equity at home. For example, primary care centres in deprived areas such as Rosengård, outside Malmö, Sweden, experience chronic vacancies.

What should the ideal global health curriculum contain? In our view, the range of disciplines necessary to understand and influence health encompasses anthropology, biology, ecology, economics, history, medicine, philosophy, political science and statistics. The history and politics of global health play particularly important roles to help understand the context of the discipline. ${ }^{7}$ As Tollulah Oni and colleagues write:

Students should be equipped with the skills required for action focused on upstream determinants where they originate (not simply addressing the negative consequences of skewed global systems), a greater engagement by the global health community with social and political sciences, and a readiness to act politically and challenge the status quo. ${ }^{8}$

\section{CONCLUSION}

We do believe that understanding health around the world is a core component of global health-no matter where you are from, most people live in other countries than your own. Comparing and contrasting countries is an effective learning tool, and evidently certain health issues are more concentrated in some countries than others. However, health issues exist, in varying degrees, in all communities, and improving health demands a 'global' view, in the widest sense of the word. We further propose that local study visits and trips should be encouraged, such as non-governmental organisations addressing social determinants of health, migration, and health centres and local health councils.

Lastly, we need the institutional support and flexibility to make these changes, without which senior staff must feel threatened in their position or their practice. We call for an open dialogue that has one thing in view: building a global health workforce that embraces and practises the achievement of equitable health for all. Yet we argue that this will only happen if we reimagine global health as a truly interdisciplinary area of research and practice-not simply public health somewhere else. As global health educators in the 21st 
century, it is our role to change the current narrative through good educational practice.

Twitter Sibylle Herzig van Wees @s_wees

Funding The authors have not declared a specific grant for this research from any funding agency in the public, commercial or not-for-profit sectors.

Competing interests None declared.

Patient consent for publication Not required.

Provenance and peer review Not commissioned; internally peer reviewed.

Data availability statement There are no data in this work.

Open access This is an open access article distributed in accordance with the Creative Commons Attribution Non Commercial (CC BY-NC 4.0) license, which permits others to distribute, remix, adapt, build upon this work non-commercially, and license their derivative works on different terms, provided the original work is properly cited, appropriate credit is given, any changes made indicated, and the use is non-commercial. See: http://creativecommons.org/licenses/by-nc/4.0/.

ORCID iD

Sibylle Herzig van Wees http://orcid.org/0000-0002-5270-1170

\section{REFERENCES}

1 King NB, Koski A. Defining global health as public health somewhere else. BMJ Glob Health 2020;5:e002172.

2 Decolonizing global health conference, 2020. Available: https://sites. duke.edu/dukedgh/ [Accessed 1 Apr 2020].

3 Mezirow J. Chapter 1: How critical thinking triggers transformative learning. In: Fostering critical reflection in adulthood: a guide to transformative and emancipatory learning. Jossey-Bass, 1990.

4 Kolb DA. Experiential learning: experience as the source of learning and development. Prentice-Hall, 1984.

5 Packard RM. A history of global health: interventions into the lives of other peoples. Baltimore, MD, USA: Johns Hopkins University Press, 2016.

6 Merriam-Webster. Merriam-Webster dictionary: global (adjective), 2020. Available: https://www.merriam-webster.com/dictionary/global [Accessed 25 Feb 2020].

7 van Wees $\mathrm{SH}$. We need to talk about guilt in global health education. Lancet 2020;395:32.

8 Oni T, Yudkin JS, Fonn S, et al. Global public health starts at home: upstream approaches to global health training. Lancet Glob Health 2019;7:e301-2. 